\title{
"Kindness to All Around": The Changing Ethics of Animal Treatment in the Middle-Class Household, 1820-1870
}

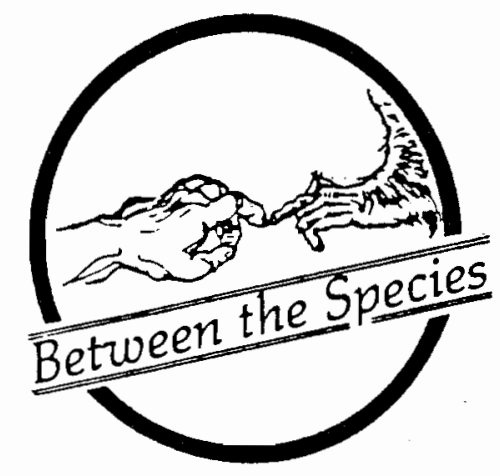

\author{
Katherine C. Grier \\ University of Utah
}

Editors' Note: 'This essay by Professor Grier and commentary by Professor Barber were presented at the Pacific Division meeting of the Society for the Study of Ethics and Animals, held in San Francisco, California, March, 1991.

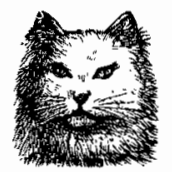

Samuel Clemens (the author Mark Twain) always was extremely fond of animals, especially cats. He recalled that he learned kindness to animals from the example of his mother in small-town Missouri in the $1830 \mathrm{~s}$ and $1840 \mathrm{~s}$. She defended cart horses from abuse by their drivers, took in scores of stray cats and would not allow her children to have pets in cages: "An imprisoned creature was out of the question - my mother would not have allowed a rat to be restrained of its liberty." Yet Mrs. Clemens lived in a slaveholding community and was, to her son's recollection, "not conscious" that slavery was an evil, having "never heard it assailed in any pulpit."1

In nineteenth-century America, contradictions in ideas, feeling, and action characterized the interactions of good, thoughtful people with the animals in their lives just as they do today. The kind of inconsistency marked in Samuel Clemens' memoir of his mother seems to be characteristic of the historical, organic growth and change of what may be called "popular" ethics.

Still, there is evidence that many nineteenth-century Americans were highly aware of, and concerned about, the quality of human thought and action regarding animals. When Caroline Cowles Richards, aged fourteen, took a walk through downtown Canandaigua, New York, with her grandfather on a fine spring day in April, 1856, she received a lesson on the subject. She recorded in her diary that night that it was "such a beautiful day I felt glad that I was alive. The air was full of tiny little flies, buzzing around and going in circles and semicircles as though they were practising calisthenics or dancing a quadrille. I think they were glad they were alive, too. I stepped on a big bug crawling on the walk and Grandfather said I ought to have brushed it aside instead of killing it. I asked him why and he said, "Shakespeare says, "The beetle that we tred upon feels a pang as great as when a giant dies." "2

Richards' diary entry is one instance of an ordinary middle-class child in Victorian America being socialized into consciousness of the feelings of another creature and encouraged to be kind. Even as Caroline had imputed a human emotion to insects she observed in flight-that of "gladness"--she deliberately stepped on another bug that was in her way. Her grandfather's admonition to her suggests that learning the proper attitudes toward other sentient beings, and adhering to them as an adult, required a high level of self-awareness and self-control.

Between 1820 and 1870, middle-class ideas about the appropriate character of animal-human relationships coalesced into the distinctive ethic that is, in many ways, still characteristic of middle-class American culture

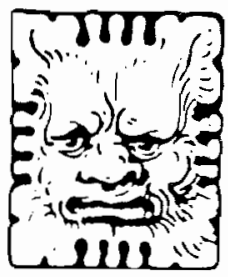


today. Undoubtedly most discussion of the boundaries of animal treatment was informal and situational. However, domestic advice books, popular fiction and poetry, natural histories for general readers, and popular religious essays frequently contained both specific suggestions for kind treatment of domestic and wild animals and rationales for greater sensitivity to animals as sentient beings. Like popular culture generally, these prescriptive sources both reflected change that had already occurred and helped shape the boundaries of acceptable treatment of animals.

During these decades more than one standard for animal treatment coexisted, and conflict between them increased in certain contexts, as in the ongoing debate over cruelty to urban cart horses and livestock in the city that culminated in the formation of the first American anti-cruelty societies in the $1860 \mathrm{~s} .^{3} \mathrm{~A}$ traditional ethic, originating in the necessities of agrarian society, continued to predominate both on farms and among the urban working classes. Rooted in the old realities of hard work with animals as both power source and agricultural product, this traditional ethic rested on the universal belief in the divinely ordained mastery of man over the earth, manifested partly through the ability of people to compel animals to serve human ends. Middle-class people grafted new ideas onto the older folk ethic of animal treatment. For example, few middle-class people seem to have criticized the right of humans to butcher animals for meat. However, advocates of kindness argued that killing for other than simple necessity, and taking pleasure in the act (as in the case of hunting), was unacceptable.

\section{The Appearance of a Distinctive} Middle-Class Culture in America

The new popular ethic of kindness was one logical extension of key ideas that shaped middle-class culture in the first decades of the nineteenth century. Evangelical Protestantism, which swept over the northeastern United States during this time, encouraged popular belief in the efficacy of individual will, the necessity of self-discipline, and the possibility of individual and social progress toward perfection. In concert with these ideas, economic and social change fostered "domesticity," a loose set of ideas that made the individual middle-class household simultaneously the front line for creating self-disciplined, successful adults, a refuge from the outside world, and a perfectible model of the world as it should be, where naked power was supplanted by love. Middle-class people believed that improved treatment of animals was evidence of rational self-discipline and benevolence, the desire to do good to others, as well as evidence of the softened feelings that both the ideal of cultivation and the canon of domesticity valued. Deep recognition of the individuality of selected animals - granting them what may be called "personhood"-also had the effect of making them family members. Thus kindness to animals became one characteristic of being middle class, and welcoming animals into the domestic circle of the family a step toward making each middle-class household a little Eden of ideal relationships.

The 1820s and 1830s saw the first full expression of a distinctive middle-class culture in the northeastern United States. A panoply of economic and social factors, which can only be noted in passing here, encouraged its flowering. ${ }^{4}$ The first was the development of new ways of working and doing business which created a sizable group of middle-class businessmen and merchants. These businesses, including new factories having scores of workers and machinery, required new ways of working, controlled by clocks. Unlike traditional artisanal and farm households, workers and owners increasingly lived away from the buildings where they spent their days--work and home were separated in actuality.

Evangelical Protestant teaching offered models for behavior that were useful in this new world of work and social life. In the decades before the Civil War, commentators repeatedly stressed that the uncontrolled human being, subject to "passions," was dangerous to him- or herself, to other innocent beings, and, finally, to the social order. Edward Jarvis, a reformer who worked with the insane, stated flatly, "We need more discipline, more control of our emotions, and desires, of our appetites and our passions. ${ }^{5}$

Middle-class people grew increasingly interested in activities such as temperance that improved individual self-control and were expressions of "benevolence," defined as "a sincere desire to promote the happiness of others" in general. ${ }^{6}$ It is not odd that this definition comes from a manners advice book-benevolence was believed to motivate all forms of doing good, and even etiquette was interpreted as one expression of it. Benevolence even was understood as one motivation for keeping pets. Sophie duPont, the adolescent daughter of the founder of the Eleutherian Mills 
gunpowder establishment, noted in a humorous 1823 "letter" to the family "newspaper" that the number of cats on the property reflected "the propensity which many people have to foster and cherish animals of various sorts" due to "an amiable cause, that of a benevolence which seeks to extend itself to surrounding objects and to promote general happiness." 7 The ethic of kindness to animals became, for some reformers, another manifestation of benevolence. The Spirit of Humanity and the Animals' Friend (1835, repr. 1855), a compilation of essays, sermons, and poems which devoted most of its pages to accounts of cruelty to animals and arguments for humane treatment, also contained discussions of human slavery, prisons, and treatment of the insane, along with general essays on moral science and practice. ${ }^{8}$

Kindness to animals seems to have been part of the education in values delivered by evangelical Protestant Sunday Schools to scores of thousands of children in the 1820s and 1830s alone. The American Sunday-School Union (1824), the largest of such organizations, offered such books as Charlotte E. B. Tonna's Kindness to Animals: or the Sin of Cruelty Exposed and Rebuked in its inexpensive Library series for $1851 .{ }^{9}$ Authors of moral education and religious texts for children often took some facet of the human relationship to animals as a theme. Right and Wrong; or Familiar Illustrations of the Moral Duties of Children (1834) discussed the right of human beings to kill animals for meat, "only we must not hurt them, when we can help it." 10 Horace Hooker's The Child's Book on the Sabbath (1835), devoted entirely to the Sabbatarian argument, offered the following lesson on the text "Thou shalt not do any work, thou, nor thy cattle" (author's emphasis), arguing that draft animals "have a right to rest on the Sabbath....Beware how you deprive them of this right, for God takes the part of the weak against the strong." 11

Change in sentiments toward animals also was a product of the creation of Victorian family life. In the private households of middle-class families, women and children also experienced change in the actual ways they spent their time and in how their roles were interpreted. Middle-class men now did the "real" work outside the home for money. Middle-class women, who of course continued to work long and hard, were now responsible for creating the lifestyle of their families through judicious consumption and social life. These changes were ratified by a bundle of common- place ideas about the appropriate roles of family members vis a vis the world "outside" each home, the canon of domesticity. ${ }^{12}$

Domesticity described the society occupied by middle-class families as two separate realms which both opposed and paralleled each other. One realm, comprised of the world of work outside the home, was rational and hard, commercial, public, and masculine. The realm of the home was the source of heartfelt feeling. It existed beyond commerce, was private, and also was decidedly feminine, a refuge from the "contagion" of a "bank-note world." 13 A psychological as well as a physical sanctuary, its occupants were bound by love and the duty to socialize children into responsible Christian adulthood, a responsibility borne particularly by mothers, who were the only constant adult presence in the home. At the same time, however, this domestic sphere also served the outside world via a series of analogies made between the moral and social development of each family and that of the larger society. Children were trained to be "good subjects of a just government" through the lessons of family governance. Harriet Beecher Stowe went so far as to call the State "but a larger family." 14 Well-ordered homes also paralleled the characteristics of a third, heavenly sphere. Catharine Beecher, sister of the author and reformer Harriet Beecher Stowe, argued in her popular advice book, The American Woman's Home (1869), that "the family state, then, is the aptest earthly illustration of the Heavenly Kingdom" and woman its "chief minister."15 This parallel created the possibility of including ideal and idyllic relationships to animals as part of the family's Eden in miniature.

\section{The Gentle Hierarchy}

The concept of divinely ordained hierarchy has been fundamental both to Western interpretation of the natural world and justification of social structures. Domesticity did not reject the concept of hierarchy, either in human families or in nature, but it attempted to soften the impact of hierarchical relationships by cloaking them in a language of service and duty, adopting the alternative notion of stewardship. Ignoring the real legal and economic disabilities of women, the notion of separate spheres argued that both were of equal value and that women had a special ability and Christian duty to serve and please others, particularly their husbands. ${ }^{16}$ Further, while 
the adult members of the household were clearly in charge, Catharine Beecher noted that the special "discipline of the family state is one of daily selfdevotion of the stronger and wiser to elevate and support the weaker members." 17

The emerging middle-class ethic of animal treatment also did not reject the concept of divinely ordained hierarchical relationships in nature. John Bigland, author of a natural history for young people published in both England and America in the 1820s, informed his readers that animals "should be subservient to the interests of man, or at least subject to his reasonable will." ${ }^{18}$ The author of 1873 's Good Morals and Gentle Manners, another textbook directed to children and families, concurred that "all animals were made for the benefit of man, directly or indirectly." 19

However, just as domesticity softened power in the family with love, so advocates of kindness to animals similarly tried to soften the implications of divine hierarchy. In this, it followed what Keith Thomas has identified as "a distinctive doctrine of human stewardship and responsibility for God's creatures," articulated centuries earlier although it did not predominate in discourse about man's relationship to the natural world before the nineteenth century. ${ }^{20}$ Advocates of kindness argued that animals were, in Harriet Beecher Stowe's words, "a sacred trust from our Heavenly Father." 21 Charlotte E. B. Tonna, author of Kindness to Animals; or, the Sin of Cruelty Exposed and Rebuked (American edition 1845) argued that animals are never really owned by people:

...one of the things that we are apt to forget when we have a beast, or a bird, or a fish, or an insect, in our power. We are too ready to say to ourselves, "This is mine, and I may do what I like to it." Not so, it is a creature of God's, not of ours; and if we do anything that he does not approve of, he will surely recon [sic] with us for it." 22

Thus, animals were ostensibly protected from human cruelty by recognition of their status as a divine trust. This Christianization of the relationships of power in families and those of humans to animals was reminiscent of earlier attempts to Christianize slavery through an argument for moral stewardship and restraint by masters to the benefit of their less civilized chatteland it suffered from the same limitations. ${ }^{23}$

\section{Training Children to be Kind}

A central tenet of evangelical Protestant advice literature for parents was the gradual growth of children into independent moral agency. An increasing number of childrearing books, however, stressed that early moral training at home was aided by children's "natural feelings of kindness." 24 The domestic sphere was, said the author of The Fireside: An Aid to Parents (1854), "the natural nursery of liberal souls, and of an enlarged, active excellence." Children's "disposition to social usefulness" was expanded when the "law of human kindness" reigned there. "Where," he inquired, "are we to look for the genuine patriot, or the sincere philanthropist, except among those true to the calls and claims of home?"25

How were small children to learn the "law of human kindness" that led to general benevolence? Many advice writers turned to the presence of domestic animals in the household as a vehicle for its inculcation. Lydia Sigourney, author of the popular advice manual Letters to Mothers (1838), addressed the question of kindness to animals in some detail as one of the three fundamental lessons of the "moral code of infancy" that laid "the foundation for a future superstructure of virtue." 26 After the lesson of obedience to parents, she suggested, the next lesson to children was "kindness to all around."

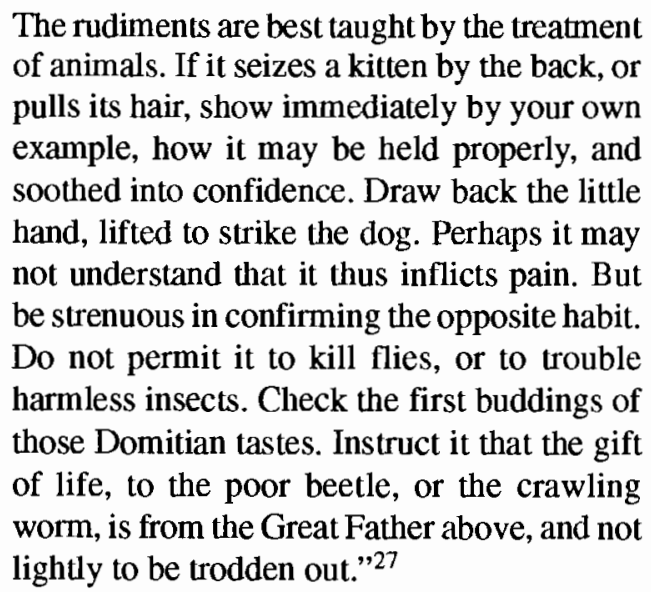

By the 1850 s, promoting kindness to animals was a commonplace of popular domestic advice literature such as Mrs. L. G. Abell's Woman in Her Various Relations (1851), which stated flatly that "nothing which will inflict pain or do injury should ever be 
allowed" and offered a list of transgressions that grouped human beings and animals together. ${ }^{28}$

Evangelical children's literature sometimes provided examples to both children and their parents of how the process of pet keeping, supervised by an adult, could be used to help create kind hearts and active moral sensibilities in children. Master Henry's Rabbit, an inexpensive children's book printed in the United States around 1840 , was one such volume and part of a series of stories intended to inculcate values in children. Each featured Henry, a boy of around seven or eight years, and his uncle, Mr. Dalben. In Master Henry's Rabbit, the boy, who is instinctively kind, is allowed to adopt a rabbit that has been injured by some village boys and their dog. His uncle, who has assessed the animal's condition and sees that "it was not so much injured but that it might be recovered" (hence a useful lesson), consents on the grounds that Henry have sole charge of the animal. (He also asks a servant to be certain that the animal "did not want anything necessary to its comfort"- just in case.) Henry cares for the rabbit for some time, but his attention is diverted by his new kite, and he forgets to feed the rabbit even after being reminded. His uncle scolds him:

"You are greatly to blame, Henry," said Mr. Dalben. "You would have done better, to have destroyed the little creature when you found it in the warren, than to keep it to perish with hunger. Go, careless boy, feed your poor rabbit now; and, in order that you may be able to feel for the poor little animal another time, I shall deprive you of your dinner today."

Henry's punishment was typical of the kind of parental discipline recommended by middle-class, evangelical Protestant advice authors. Its goal was self-regulation through self-awareness, and in this instance, its object lesson was creating awareness of the obligations of stewardship toward a dependent being and encouraging empathy with the feelings of another living creature. Indeed, young Henry "humbled himself before God for this sin, and prayed earnestly for a better heart." 29

Why was it important for middle-class parents to be alert to childhood cruelty? By emphasizing the direct connection between the moral climate of the individual household and that of the larger community, domesticity recast childhood cruelty and kindness to animals as a significant clue to the future moral condition of society. In the moral development of children, animals could stand in for human beings. The argument that cruelty to animals makes humans cruel to each other was nol new to the nineteenth century, being one thread of Christianity's ambivalent tradition of thought about the appropriate relationship of humans and other species. ${ }^{30}$ In the eighteenth century, it occasionally appeared in fiction and popular visual arts. For example, William Hogarth's famous series of prints The Four Stages of Cruelty (1750-51) pressed the case that the children who torment cats and dogs today would end as murderers.

However, domestic advice literature published between 1820 and 1870 made this moral equation a commonplace, with its own conventions. Childhood cruelties contained the seeds of adult acts having wider social and political implications; parents (that is, mothers) had to be exceedingly vigilant. Authors often singled out the "wanton sport of torturing poor insects," an activity which probably seemed harmless enough to mothers who spent considerable time and effort ridding themselves, their children, and their furnishings and food of swarms of such pests in the days before pesticides and even window screens. ${ }^{31}$ John Bigland warned that "Although this horrid propensity may, at that early period of life, be attributed to a want of reflection, yet, if indulged, it may settle into a habit of cruelty, and render [children's] hearts callous, not only to the sufferings of the brute creation, but to those of their own species." 32

While each woman presided over her "state in miniature," her conventional feminine attributes - a more feeling nature, gentleness, and the capacity for deep maternal devotion--shaped the kind of power wielded there. Softened feelings and the "law of kindness" in the "softening, sanctifying environments of home" changed the character of authority from physical and economic power to Christian love and influence. ${ }^{33}$ The popular ideal of civilized progress also employed the concept of "softening" through the ideal of cultivation. Inexpensive manners books, published in large numbers throughout the nineteenth century, offered a formulation of the "amiable character" that connected benevolence, the general impulse to do good, with "true delicacy," the sensitivity that allowed individuals to enter the feelings of others. The anonymous author of A Manual of Politeness (1837) explained that the softened person's sensibility "has a quick sense of what may give pleasure or pain, and 
teaches us to pursue the one and avoid the other; and a refined understanding points out the surest means of doing this in different circumstances." 34

By the 1850 s, affection for pets generally, and the experience of caring for pets, was regarded as a potent agent for softening children's hearts. "Indeed, love in any form, and to any thing," noted Rev. A. B. Muzzy, "is an elevating motive. It is good that a child be taught to love the very animals... who can doubt that many a heart, both of the happy and sad, has been made better by the multitudes of parrots, lap-dogs, canaries, \&c., which have been objects of affection." 35

In 1868, Sarah Josepha Hale, author and editor of the influential women's magazine Godey's Lady's Book, published an essay, "Pets and Their Uses," which emphasized the salutary effect of pet-keeping on boys: "a great preventative against the thoughtless cruelty and tyranny they are so apt to exercise toward all dependent beings!"36 The socialization of boys, future leaders of both business and politics, into kindness was a particularly weighty responsibility for the middle-class mother. Popular understanding saw boys' natures as more inclined to casual cruelty than girls', not without reason, given some of the common types of boys' play of the period. Memoirs of nineteenth-century childhood suggest that bird-nesting (robbing both eggs and baby birds) and casual hunting of song-birds and small animals were typical outdoor pastimes. ${ }^{37}$ Further, throughout the nineteenth century even middle-class boys often had casual daily contact with the world of adult working-class men, who still fought cocks and dogs for sport. ${ }^{38}$

Boyhood cruelty to animals even had worrisome implications for the future of the American republic. Lydia Sigourney, for example, noted that, while she was not certain how early childhood lessons of kindness were absorbed, intervention during "infancy" (before the age of six or seven) was important, citing American history as evidence:

...those baleful dispositions, which in desolate human happiness are often early developed. It was Benedict Arnold, the traitor, who in his boyhood loved to destroy insects, to mutilate toads, to steal the eggs of the mourning bird, and torture quiet, domestic animals, who eventually laid waste the shrinking, domestic charities, and would have drained the lifeblood of his endangered country. ${ }^{39}$

\section{Welcoming Animals into the Domestic Circle}

By the mid-nineteenth century, some authors discussed welcoming animals into the home as pets more consciously as a positive good: Sarah Josepha Hale, the influential editor of Godey's Lady's Book, offered a set of reasons why which sounds much like the justifications for childhood pet keeping offered today: "when the love of pet animals can be judiciously cultivated, it leads to the love of natural history and intellectual improvement, as well as to thoughtful tenderness and moral sensibility." 40

Some authors argued that humans benefitted from daily contact with certain animals precisely because of the creatures' exemplary characters. At home, children could learn "respect for the good qualities of the inferior creation" by studying the family dog while their mother described "the virtues of his race...their fidelity and enduring gratitude."41 Although moral philosophers argued that animals were "destitute of any moral faculty," the common use of animals as moral exemplars in such literature suggests that, in popular thought, certain animals became real moral actors filling a cultural role as metaphorical human beings. ${ }^{42}$

When animals received recognition for their emotional responsiveness, their role in fostering the ethic of kindness also became more active. Catharine Beecher felt that pets' displays of affection could "awaken corresponding tenderness and care" in children. When Miss Beecher credited domestic animals with "intuitive perceptions of our emotions which we cannot conceal," she granted them emotional sensitivities which would have been perceived by her readers as much like the delicacy of refined people, especially women. ${ }^{43}$

As they were incorporated into the emotional structures of middle-class families, pet animals were described as having emotions which paralleled their human guardians in both range and intensity-devoted love, happiness, grief, and mental as well as physical suffering. ${ }^{44}$ Some of this attribution was undoubtedly based on the simple proximity of humans and their pets. However, the selective granting of "personhood" to animals was an artifact of middle-class culture. Fiction, anecdote, and the iconography of prints and book illustrations increasingly promoted a popular vision of animal emotional life that had the domestic life of middle-class human beings as its point of reference.

Middle-class people were urged to value types of animals that seemed to exhibit the characteristics which 
they found desirable in themselves. Caged birds were extremely popular pets, because of the relief they provided from the silence of a world without recorded music, but also because of their domestic habits:

Birds are remarkable for the ingenuity with which they construct their nests, and the care and tenderness they show to their young. They have memory, knowledge, gratitude, affection, and even imagination, for they dream. ...45

Familial sentiments in animals that paralleled those of the middle-class family were the object of delight, as the image "Increase in the Family" suggests (fig. 1). Prints of animal families, from wood grouse to barnyard cats, were extremely popular throughout the nineteenth century because of their celebration of domesticity.

Encouraged by appreciation for the domestic qualities of animal families, middle-class families increasingly recognized the individuality of specific animals in the middle-class household, granting them a special status that may be termed "personhood." 46 "Personhood" is defined as "the quality and condition of being an individual person." The word "person" itself usually refers to human beings but in a general philosophical context can refer to any "self-conscious or rational being." Personhood, then, is an elastic concept and may be useful in describing the level of regard Victorian Americans felt toward selected animals in and around their households. Not all pets, nor animals kept largely as decor or as miniature natural history exhibits (the denizens of aquaria, for example), were recognized as persons. Here "person" will be used in an admittedly anthropocentric sense, parsed from the meaning discussed above, to encompass any animal that a human recognizes as having significant individuality.

Charlotte E. B. Tonna's Kindness to Animals: or the Sin of Cruelty Rebuked described the emotional motivations of animals, including her own pets, in a manner that invited readers to consider them as persons:

...the animals are very sensible, and very willing to do their best. They are fond of being praised and rewarded; they become much attached to those who treat them kindly; and when they are so attached, they are very happy.... ${ }^{47}$
She illustrated her points with her own dogs, whose characters were discussed in some detail, and with horses.

The indefatigable Harriet Beecher Stowe was perhaps the first truly popular literary proponent of this enlarged view of the individuality of animals, including the role of some as family members. In the $1850 \mathrm{~s}, 1860 \mathrm{~s}$ and $1870 \mathrm{~s}$, she pressed her case through children's stories and didactic essays, as well as some adult fiction (We and Our Neighbors, 1875) that employed dogs as protagonists. ${ }^{48}$

The serial story titled "Our Dogs" is notable for the accuracy of its descriptions of animal behavior, from chewing shoes to frantic enjoyment of carriage rides. ${ }^{49}$ The children of the household and the dogs are described in the same tone and vocabulary; in fact, apart from occasional lapses into the florid prose of Victorian popular fiction, the descriptions of dogs are much like those found in modern popular non-fiction about pets (the books of Roger Carras, for example). Each dog is described in human terms--one as "a highlyappreciated member of society," another as a "friend and playfellow," a third as "a little black individual" who is "not very prepossessing in appearance and manners, but possessed of the very best heart in the world." 50 In the follow-up piece, "Dogs and Cats," Stowe points out that each of her family dogs "had as much his own character as if he had been a human being," and that such individuality is a potential characteristic of "every animal." 51

Certain behaviors on the part of nineteenth-century people suggest when a particular animal had become a person, as when a funeral was held and a marked grave provided for the animal. Proper Victorian burials for beloved animais and the creation of pet cemeteries on family grounds were not uncommon; two examples will suffice here. In 1837, the Rumford family of Wilmington, Delaware constructed on its property a tall wooden obelisk as a marker for "Faithful Carlo;" over time it became the family marker for other dogs, following the practice in human cemeteries. Two nearby painted wooden gravestones also listed the names of "favorite cats." ${ }^{52} \mathrm{H}$. W. Delong's memoir of an upstate New York boyhood in the 1850 s and 1860 s includes an account of a funeral ceremony for a monkey named Jocko, accidentally killed by a blow from an axe: "Jocko was given a decent interment and a suitable headstone on which in verse was recorded his virtues and a pathetic account of his taking off, embellished with a free hand picture of the axe that laid him low." 53 
Having a formal photographic studio portrait made of the animal or the animal and human owner together similarly suggests high regard and sentiment, particularly when pictorial conventions used for human beings are employed. Until home photography became common in the $1880 \mathrm{~s}$, families often took animals for studio portraits. ${ }^{54}$

Thus, while the middle-class ethics of kindness enjoined cruelty to all animals generally, personhood was a quality that human beings granted selected animals, perhaps most often in the context of the family. But what kind of "person" was a so designated animal?

\section{The Animal as Servant vs. the Animal as Child}

There is preliminary evidence suggesting that, in the eighteenth and early nineteenth centuries, the paradigmatic relationship between domestic animals that were the objects of sentimental attachment and their owners was that of master and faithful servant. Take, for example, an advertisement for a lost dog published in Philadelphia in 1796. Such ads were always for valued animals, either working dogs or, less often, "ladies' dogs" that were companion animals. "Romp" was a liver-and-white "Half bred pointer bitch... low and very square before" (that is, with the broad chest of an overweight dog), with one ear "a good deal cut and torn away." Romp"s owner offered a three-dollar reward for her return, a goodly sum but less than was typically offered for return of a prime hunting or guard dog or breeding bitch at the time. The ad explained that this was because she was "valued only as an old servant," that is, no longer as a worker but as a dependent who, like some elderly human servants, continued to receive support in respect for a lifetime of work..$^{55}$

The notion of the animal as faithful servant did not disappear as one model for animal-human relationships in the nineteenth century. It seemed à propos to working animals in particular. However, domesticity made the relationship between mother and child paradigmatic; hence the model for the personhood of selected animals in middle-class households was the young child and his relations with his mother. It is telling that, throughout the nineteenth century, the term "pet" was used interchangeably to describe both children and animals. ${ }^{56}$

Comparisons of child-rearing literature and discussions of pet keeping and kindness to animals confirm the formulation of "pet as child." Both kinds of advice literature assumed that children and domestic animals were, at root, innocent creatures who craved the proper kind of adult guidance. While Lydia Sigourney described a boy who ran to his mother crying "My goodness grows weak...help me to be good," Charlotte Tonna informed her readers that the animal "wants the help of your reason to keep him from doing wrong; and he wants you to explain to him how he may please you. ${ }^{\circ 7}$ Later, dog training books would use the parallel between children and puppies routinely: "Young dogs, like young people, must sometimes be coerced," noted one author, but "securing the respect and affection of the pupil" and exhibiting "kindness and imperturbable patience" were better educational techniques. "Talk to him as you would to a child. ... The shepherd pup is much like a child; he is a great imitator." 58

\section{The Limits of Personhood: Euthanasia}

When middle-class people faced the question of euthanizing newborn or injured animals, the pragmatic limits of Victorian regard for the domestic qualities of animals, and raising of specific animals to the status of persons in the family, became plain, just as they do when similar decisions are made today. Although male livestock was customarily neutered-the male calf became the beef steer or the working ox, the male horse became the manageable working gelding - the practice of neutering male cats and dogs was not customary until the twentieth century. Neutering females was a more complicated problem; it has rarely been done with large animals, and it required considerable advances in smallanimal veterinary medicine. Thus, pet owners were frequently faced with surplus populations for which they could not care and with animals whose injuries and health problems were beyond the limited veterinary knowledge of the period. Drowning and shooting were the two common and unpleasant everyday solutions. ${ }^{59}$

In an 1865 essay for children, "Aunt Esther's Rules," Harriet Beecher Stowe informed children that, "when there were domestic animals about a house that were not wanted in a family, it was far kinder to have them killed in some quick and certain way than to chase them out of the house, and leave them to wander homeless, to be starved, beaten, and abused," victims of people who had not absorbed the middle-class ethic of kindness. Taking responsibility for the deaths of such animals (Stowe used the universal example of "unwanted kittens") was "real brave humanity," but it 


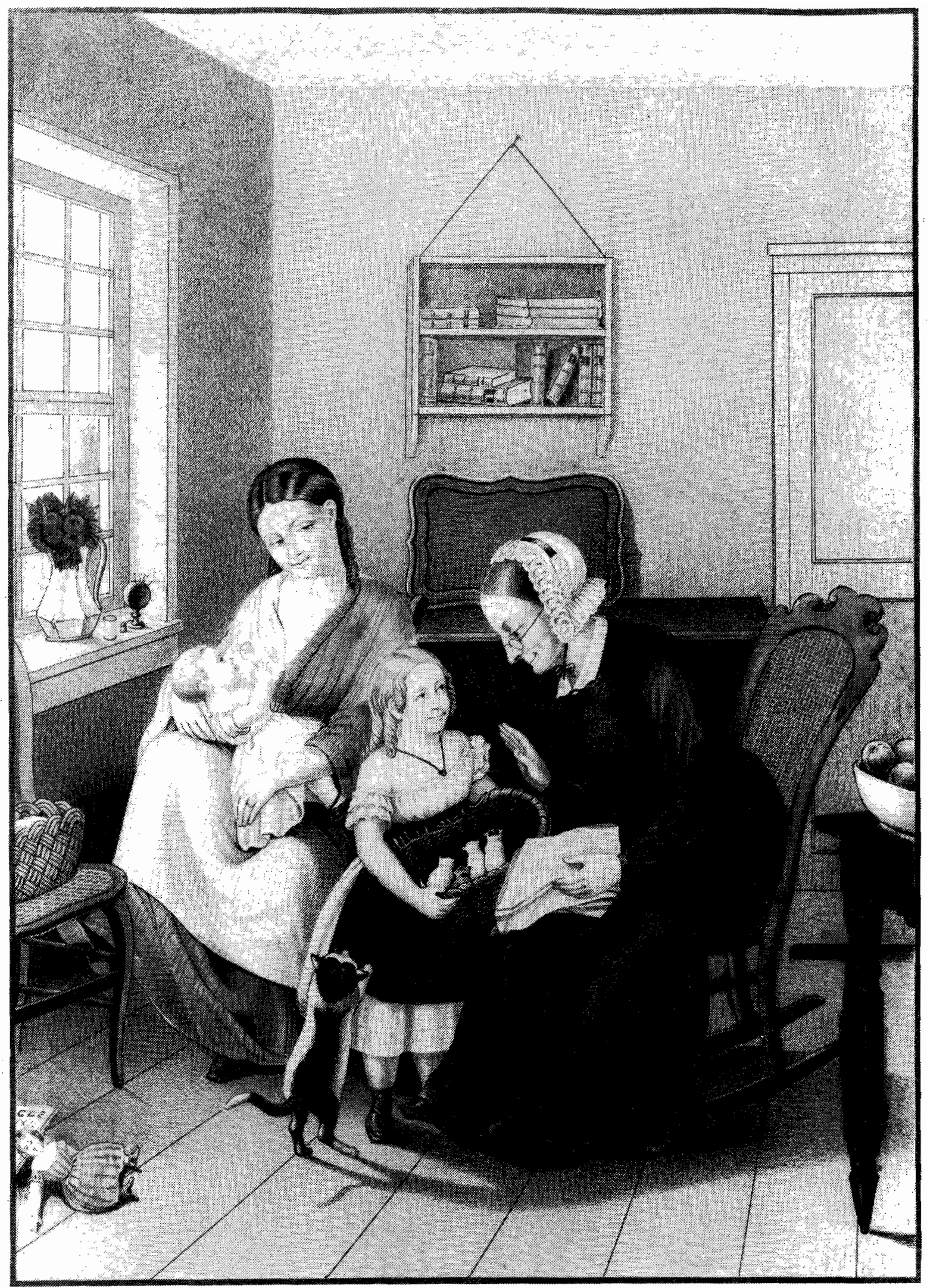

Figure 1. Increase in the Family, colored lithograph published by E. B. and E. C. Kellogg, Hartford, CT, c. 1850. Courtesy The Harry T. Peters "America on Stone" Lithography Collection, Smithsonian Institution. 
was important that the methods used were "the kindest and quickest method of disposing of one whose life must be sacrificed." 60

Three decades earlier, Charlotte Tonna also had acknowledged the necessity of euthanizing unwanted infant animals. However, in keeping with respect for animals' domestic qualities, she urged sensitivity to the family feelings of the mother, asking her readers to allow one kitten or puppy to live, ameliorating both mental distress along with the physical torment of her unused milk and arguing against the "exceedingly inhuman" practice of "putting the young ones to death in the mother's sight....an outrage of the tenderest feelings of nature." 61

Euthanizing animals must have been as difficult for sensitive souls then as it is now. In the 1820 s, Sophie duPont and her siblings were unable to bring themselves to drown excess kittens. Instead, they did just what Harriet Beecher Stowe later decried; they carried them across the Brandywine Creek and hoped that they found homes with cousins and friends. ${ }^{62}$ Cerlainly, discomfort at the decision to dispose of such animalsand coming to terms through ritualizing such deathsis suggested in Harriet Beecher Stowe's use of the term "sacrifice," a concept which, as a recent ethnography of the culture of animal laboratories suggests, may make the inevitable conflict more bearable when recognition of both animal sentience and human responsibility for animal death occurs. ${ }^{63}$

Inside the private world of the middle-class family, then, animals became important adjuncts for inculcating self-control, benevolence, empathy, and even the capacity for love in children. Selected animals were the object of deeper levels of regard for their perceived moral and emotional characters. Ultimately some animals became more than pets; they were welcomed into the family circle as persons, a status in this instance which was loosely comparable to that of young children.

\section{Killing, Hunting, and the Passions}

Killing animals was an activity that middle-class culture recognized as having dangerous implications for the killer, and its acceptable boundaries needed to be marked. Proponents of the ethic of kindness defined appropriate killing of animals as marked by two characteristics. The first, limiting the suffering of livestock before the act and ameliorating pain in the act of killing, was a commonplace in moral education tracts for both children and adults. ${ }^{64}$ The second requirement was a certain kind of rational, selfcontrolled behavior on the part of the human beings doing the killing.

In the debate over appropriate killing, middle-class culture abhorred unkindness to animals for another reason: it revealed altogether too well how ephemeral civilized progress could be by exposing the savage in adult men. Defining proper killing marked another cultural boundary that allowed middle-class people to define themselves as humane, ergo fully human, and other people as less than fully human, as brutes and savages. ${ }^{65}$

Popular understanding of human nature in the nineteenth century accepted that the mental and physical characteristics of humans were hierarchical; "higher" faculties were the spiritual, intellectual, and moral natures, and the "lower" faculties, "appetite and sense." 66 The lower faculties, which humans shared with animals, had the potential of becoming over-stimulated in a wide variety of ways - from contact with intoxicating liquors, from the wrong kinds of food, or from activities that appealed only to the senses. ${ }^{67}$

"Fishing and hunting for mere sport" were among the "exciting and pernicious amusements" targeted by middle-class advice writers. ${ }^{68}$ While the new ethic of kindness did not forbid killing animals, the first difficulty came when the participants seemed to exhibit "the love of killing," a fundamental breakdown in both empathic thought and self-control. ${ }^{69}$

Between 1820 and 1870, a few authors moved beyond their concern for the moral condition of human killers to an argument on behalf of the right of the prey "to enjoy the happiness of its physical nature unmolested," but the most important argument against hunting as a recreation was its effect on its human practitioners if it was not, in Francis Wayland's phrase, "innocently" performed as a necessity. ${ }^{70}$ Killing "merely for sport," which included not only hunting but the oldtime blood sports such as cockfighting, aroused human passions, the very demons that early inculcation of selfcontrol and duty were intended to thoroughly suppress. "The savage instincts of man are most strikingly displayed in those enjoyments which are derived from the shedding of the blood of beasts or man," warned one author. Because such passions were echoes of man's primitive state, expressing them was literally "one of the relics of our barbarism," a step backward from the progress of civilization. ${ }^{71}$ In reality, its critics were 
unable to eliminate hunting for sport as a middle-class recreation, and this kind of criticism still reemerges as public debate every hunting season.

Whether setting guidelines for killing or using domestic animals as human stand-ins for inculcating humane values, the ethic of kindness to animals added its piece to the process of middle-class self-definition between 1820 and 1870 . With their focus on the heart of each single individual and the central importance of the private household, evangelical Protestant values and the canon of domesticity almost certainly played a large role in the tendency, then and now, to see the issues of human-animal interaction as a series of exercises in microethics, where selected animals are gifted with special regard and issues such as killing are handled as series of separate cases.

\section{Notes}

${ }^{1}$ Samuel Clemens (Mark Twain, pseud.), The Autobiography of Mark Twain, Charles Neider, ed. (New York: Harper and Row, 1966), pp. 29-30, 32.

${ }^{2}$ Caroline Cowles Richard, Village Life in America 1852 1872. Including the Period of the American Civil War as Told in the Diary of a School-girl. (1908; repr Williamstown, MA: Corner House Publishers, 1972), pp. 61-62.

${ }^{3}$ James Turner, Reckoning with the Beast: Animals, Pain, and Humanity in the Victorian Mind (Baltimore: The Johns Hopkins University Press, 1980), pp. 45-52.

${ }^{4}$ For two detailed case studies of the emergence of middleclass culture in the northeastern United States, see Paul E. Johnson, A Shopkeeper's Millennium: Society and Revivals in Rochester, New York, 1815-1837 (New York: Hill and Wang, 1978); Mary P. Ryan, Cradle of the Middle Class: The Family in Oneida County, New York, 1790-1865 (New York: Cambridge University Press, 1981).

${ }^{5}$ Edward Jarvis, Address, Delivered at the Laying of the Corner Stone of the Insane Hospital, at Northampton, Massachusetts (Northampton, 1856), reprinted in David Allmendinger, Jr., ed. The American People in the Antebellum North (West Haven, CT: Pendulum Press, Inc. 1973), p. 122.

${ }^{6}$ A Manual of Politeness (Philadelphia: W. Marshall \& Co., 1837), p. 275.

${ }^{7}$ Betty-Bright Low and Jacqueline Hinsley, Sophie duPont, a Young Lady in America: Sketches, Diaries \& Letters 1823-1833 (New York: Harry N. Abrams, Inc., 1987), p. 87.

${ }^{8}$ The Spirit of Humanity, and the Animals' Friend; Extracted from the Productions of The Enlightened and
Benevolent of Various Ages and Climes (Albany: New York: Joel Munsell, 1855).

${ }^{9}$ The most recent history of the American Sunday School movement is Anne M. Boylan, Sunday School: The Formation of an American Institution, 1790-1880 (New Haven: Yale University Press, 1988). She reprints the 1851 ASSU advertisement for the "Cheap Sunday-School and Family Library No. 2" on page 51.

${ }^{10}$ Right and Wrong, p. 35.

${ }^{11}$ Horace Hooker, The Child's Book on the Sabbath (New York: American Tract Society, 1835), pp. 157-158.

12 The most cogent discussion of, and best introduction to, domesticity remains Nancy F. Cott,The Bonds of Womanhood: Woman's Sphere in New England, 1780-1835 (New Haven: Yale University Press, 1977).

${ }^{13}$ Sarah Josepha Hale, Ladies Magazine (1830), quoted in Nancy F. Cott, The Bonds of Womanhood, p. 68.

${ }^{14}$ Harriet Beecher Stowe [Christopher Crowfield, pseud.], "Woman's Sphere," in The Chimney Corner (Boston: Ticknor and Fields, 1868), vol. 8 of The Writings of Harriet Beecher Stowe (Cambridge, MA: The Riverside Press, 1896), p. 252. An extended version of this line of thinking may be found in a small collection of essays published by Almira Seymour, Home: The Basis of the State (Boston: A. Williams and Company, 1869).

${ }^{15}$ Catharine E. Beecher and Harriet Beecher Stowe, The American Woman's Home, or Principles of Domestic Science, (1869, repr. Hartford, CT: The Stowe-Day Foundation, 1987), p. 18.

${ }^{16}$ Nancy F. Coth, The Bonds of Womanhood, pp. 70-73.

${ }^{17}$ Catharine E. Beecher and Harriet Beecher Stowe, The American Woman's Home, p. 18.

${ }^{18}$ John Bigland, A Natural History of Animals (Philadelphia: Jobn Grigg, 1828), p. 187.

${ }^{19}$ Francis Wayland, D.D., LL.D., The Elements of Moral Science, rev. ed. (Boston: Gould and Lincoln, 1865, 1871), p. 395; Alex M. Gow, A.M., Good Morals and Gentle Manners. For Schools and Families (New York and Cincinnati: Wilson, Hinkle and Company, 1873), p. 136.

$$
{ }^{20} \text { Ibid., p. } 24 .
$$

${ }^{21}$ Harriet Beecher Stowe, "Dogs and Cats" (1866 or 1867) in Stories and Sketches for the Young, vol. 14 of The Writings of Harriet Beecher Stowe, Riverside Edition. (1896; repr. New York: AMS Press, Inc., 1967), p. 109. See also Francis Wayland, The Elements of Moral Science, p. 395: "They as much as ourselves, are under his protection." 
22 Charlotte E. B. Tonna, Kindness to Animals; or, the Sin of Cruelty Exposed and Rebuked. Rev. ed. (Philadelphia: American Sunday-School Union, 1845), p. 13. Harriet Beecher Stowe presented her young readers with a similar veiled threat of divine accountability: "Our Lord says not even a little sparrow falls to the ground without our Heavenly Father, and we may believe that his eye takes heed of the disposition which we show toward those defenseless beings whom he thinks worthy of his protection." "Dogs and Cats," in Stories and Sketches for the Young, op. cit., p. 109.

${ }^{23}$ David Brion Davis, The Problem of Slavery in Western Culture (Ithaca, New York: Cornell University Press, 1966), Chapter Seven: "the Legitimacy of Enslavement and the Ideal of the Christian Servant: The Failure of Christianization," pp. 197-222.

${ }^{24}$ Mrs. Louisa Hoare, Hints for the Improvement of Early Education and Nursery Discipline, 3rd ed. (Dover: Samuel C. Stevens, 1826), p. 36.

${ }^{25}$ Reverend A.B. Muzzy, The Fireside: An Aid to Parents (Boston: Crosby, Nichols, and Company, 1854), p. 7.

${ }^{26}$ Lydia Sigourney, Letters to Mothers, 6th ed. (New York: Harper, 1846), p. 41.

${ }^{27}$ Ibid., pp. 35-36.

${ }^{28}$ Mrs. L.G. Abell, Woman in Her Various Relations (New York: R. T. Young, 1851), p. 53.

${ }^{29}$ Master Henry's Rabbit (Troy, NY: n.p., n.d. (circa 1840), pp. 10-11.

${ }^{30}$ Keith Thomas cites, for example, Thomas Aquinas, Summa contra Gentiles, iii, 113, in his Man and the Natural World.

${ }^{31}$ Reverend A.B. Muzzy, The Fireside, p. 74.

32 John Bigland, op. cit., p. 186.

${ }^{33}$ Reverend A.B. Muzzy, The Fireside, p. 8.

${ }^{34}$ A Manual of Politeness, p. 276.

${ }^{35}$ Reverend A.B. Muzzy, The Fireside, pp. 141-142.

${ }^{36}$ Sarah Josepha Hale, Manners; or, Happy Homes and Good Society All the Year Round (1868, repr. New York: Arno Press, 1972), p. 244. While boys needed to be "humanized," little girls also benefited from the experience of caring for pets, although they were naturally kind, "because, as sisters and mothers, they must help and teach boys in whatever things are good, tender and lovely."

${ }^{37}$ See, for example, William Lyons Phelps (b. 1865) for recollections of casual hunting of songbirds during his boyhood in William Lyons Phelps, Autobiography with Letters (New York: Oxford University Press, 1939), pp. 52, 59-60; H.W. Delong (b. 1851), Boyhood Reminiscences: Danville, N.Y., 1855-1865 (Dansville, New York: F.A. Owen Publishing Company, 1913), p. 56, for an account of boyhood hunting of muskrats for pin money.

${ }^{38}$ Claudia Bushman, ed. "Life Along the Brandywine Between 1880 and 1895 by Samuel Canby Rumford, Part II," Delaware History 23, 3 (Spring-Summer 1989): 202 203, 205.

${ }^{39}$ Lydia Sigourney, Letters to Mothers, pp. 37-38.

${ }^{40}$ Sarah Josepha Hale, Manners, p. 244.

${ }^{41}$ Lydia Sigourney, Letters to Mothers, p. 98.

${ }^{42}$ Francis Wayland, The Elements of Moral Science, p. 395.

${ }^{43}$ Catherine Beecher and Harriet Beecher Stowe, The American Woman's Home, p. 394.

44 The Household Book of Pets (New York: Dick and Fitzgerald, 1866), p. 37.

${ }^{45}$ Book of Household Pets, and How to Manage Them (New York: Dick and Fitzgerald, 1866), p. 5.

46 While not particularly graceful, "personhood" is a term that has recently appeared in some discussions of animal rights. See Tim Ingold, "Introduction," in Tim Ingold, ed., What Is an Animal? (London: Unwin Hyman, 1988), p. 9: "If we accept that animals other than human beings may be conscious, intentional agents, then we have also to ascribe to them personal as well as natural powers. That is, we are forced to recognize that they embody attributes of personhood which in the West are popularly identified with the condition of humanity."

"Personhood" is a modern term; the Oxford English Dictionary lists its first appearance in 1959; its use then was theological.

${ }^{47}$ Charlotte E. B. Tonna, Kindness to Animals; or; the Sin of Cruelty Rebuked, p. 19.

${ }^{48}$ Novels that used dogs as plot devices included $A$ Dog's Mission (Boston: Houghton Mifflin Company, 1881) and We and Our Neighbors (New York: J. B. Ford and Company, 1875).

${ }^{49}$ This body of material first appeared in the children's magazine Our Young Folks and was collected in book form in 1867 .

${ }^{50}$ Harriet Beecher Stowe, "Our Dogs," in The Writings of Harriet Beecher Stowe, Riverside Edition, Vol. 16 (1896; repr New York: AMS Press, Inc., 1967), pp. 71, 78, 79. 
51 Harriet Beecher Stowe, "Dogs and Cats," in The Writings of Harriet Beecher Stowe, Riverside Edition, Vol. 16 (1896; repr. New York: AMS Press, Inc., 1967), p. 103.

52 Claudia Bushman, ed. "Life Along the Brandywine Between 1880 and 1897 by Samuel Canby Rumford (Part I)," Delavare History 23, 2 (Fall-Winter 1988), pp. 116-117. The monument is depicted in Figure 11, p. 117. It was kept in repair until the family sold the downtown property and the house was demolished in 1934.

${ }^{53}$ H. W. Delong, Boyhood Reminiscences, p. 43.

54 The photographic archives of the Society for the Preservation of New England Antiquities, for example, contain daguerreotypes (the earliest type of photography) of people and dogs from around 1840. Pet photography began as soon as photography itself was available.

55 Advertisement, Pennsylvania Packet (Claypool's American Daily Advertiser), no. 5441 (September 15, 1796). This and many other useful advertisements relating to animals from American newspapers of the eighteenth century can be found in the "Prime File," collections of the Winterthur Library, Winterthur, DE.

${ }^{56}$ According to the Oxford English Dictionary, the word "pet" originated with orphaned lambs requiring particular shelter and care from shepherds. Mary Lynn Stevens Heininger offers a brief discussion of the increasing number of comparisons made between children and baby animals, along with an illustration of a toy chair labelled "Pet" in "Children, Childhood, and Change in America, 1820-1920," p. 15.

${ }^{57}$ Lydia Sigourney, Letters to Mothers, p. 39; Charlotte Tonna, The Sin of Cruelty Rebuked, p. 41.

58 W. A. Wickham, Practical Training of the Shepherd Dog (Tipton, Iowa: The Author, 1891), pp. 72, 80.

${ }^{59}$ In a set of published "letters" to her daughters about a year spent in Florida, Harriet Beecher Stowe described the decision to shoot a badly injured cat: "we were thankful that we had the power, by swift and painless death, to put an end" to the animal's suffering. "So a pistol-ball sent Puss to the land where the good cats go...." Harriet Beecher Stowe, Palmetto-Leaves (Boston: James R. Osgood and Company, 1873), p. 151.

${ }^{60}$ Harriet Beecher Stowe, "Aunt Esther's Rules," in Stories and Sketches for the Young, vol. 16, The Writings of Harriet Beecher Stowe. Riverside Edition (1896; repr. New York: AMS Press, Inc., 1967), pp. 111-112.

${ }^{61}$ Charlotte Tonna, Kindness to Animals, pp. 47-48.

62 Betty-Bright Low and Jacqueline Hinsley, Sophie duPont, p. 95.
${ }^{63}$ Arnold Arluke, "Sacrificial Symbolism in Animal Experimentation: Object or Pet?,"'Anthrozoos 2, 2 (Fall 1988): 98-117. For further elaboration of some of the author's ideas, see Arnold Arluke, "Living with Contradictions: Responses to Comments," Anthrozoos 3, 2 (Fall 1989): 90-99.

${ }^{64}$ Marianne (pseud.), Right and Wrong, p. 35; Francis Wayland, The Elements of Moral Science, pp. 395-396; Alex Gow, Good Morals and Good Manners, pp. 136-137.

65 James Turner describes how cruel sport, and by extension cruelty generally, to animals grew to be described as an exclusively working-class phenomenon in Reckoning with the Beast, pp. 54-56.

${ }^{66}$ Reverend A.B. Muzzy, The Fireside, p. 127.

67 For a discussion of the problem of appetites, "stimulation," and diet reform as one response to the problem, see Harvey Green, Fit for America: Health, Fitness, Sport, and American Society (New York: Pantheon Books, 1986), pp. 41-45.

${ }^{68}$ Mrs. L. G. Abell, Woman in Her Various Relations, p. 53.

${ }^{69}$ Alex M. Gow, A.M., Good Morals and Gentle Manners, p. 137.

${ }^{70}$ Francis Wayland, The Elements of Moral Science, p. 395.

${ }^{71}$ Alex M. Gow, A.M., Good Morals and Gentle Manners, pp. 136-137.



